\title{
ROCK 'N' ROLL ALIENS
}

The looks and the lifestyle.

\section{BY RALPH GRECO JR}

$\mathrm{I}$ had just seconds to leap across the stage and catch Dr Malacuplus before he made off with the orb. The Latex Kids were blistering through their latest sevenminute epic guitar assault, and Sinthia Slide, the band's lead singer and my third cousin once removed, was adopting her usual stage pose, channelling one-quarter Janis Joplin, one-quarter Rip Taylor, another part classic Medusa and one-quarter that tiger who had had enough with Siegfried and Roy. As she scared/delighted/ aroused the crowd, I realized that my only chance was to use her in a way that would've had her snapping her whip at me if I hadn't been the band's security, confidant and benefactor. As Sinthia set her hips, spread her thighs (as best she could in what she wore) and unfurled her red latex dress down to her knees, she created for me a tighterthan-tight trampoline. I leapt from my perch atop the wall of Marshall stacks, bounced off the front of Sinthia's dress and catapulted over the bands' collective heads straight on to the back of that bald, smelly doctor.

Of course, most of the audience at the Steam Works, an outpost of 7 th Avenue and nowheresville New Jersey, thought my aerobatics were part of the show. The LKs truly deliver for their fans. That a six-foot guy with a crew cut, jack-boots and split rivet jeans could come tumbling down from some amps, bounce off the petite lead singer as she held her dress out, shoot across the stage and land on the arch-nemesis of our entire lifestyle community - the doctor liked to steal much more than just off-world glowing orbs of power - prompted a fiveminute round of applause and not one raised eyebrow. All of which went far in bolstering my good feelings for the people who, like me, are into latex, leather and lace.

"You said he was bound to show before the end of the season," Sinthia said as the band and I congregated backstage, sipping a round of cold ones.

"I hoped putting the orb out there in full view would pull him out."
"Amazing half-gainer off my pelvis, cousin," she added.

The other three band members - drummer Trudy Sticks, her bassist brother Randee (no last name), and the truly gargantuan, gaunt and to all intents and purposes mute (he truly let his instrument speak for him most of the time) lead guitarlead singer as she made her way across the room in her six-inch-heel patent-leather ist Larry Candy Cane - and I gazed at the

red leather vest and jodhpurs on), I knew I could relax a bit. I had dispatched the evil doctor, secreted him in the back of my van after a quick knockout punch, and I once more had the orb safely tucked under my long trench. The members of LK were never as comfortable staring at the thing as they were Sinthia's butt - seeing as the orb was not of this world.

I was picked as the orb's keeper because the aliens who made it saw I ran with a community. Our goth-that-wasfetish-that-was-rock-and-roll crowd was not easily unnerved and was one they wanted to infiltrate before they made their presence known further to us humans. The charge for the powers the orb gave me - a mere human - was a fee I was collecting as I bent to grab the band's sweaty and slightly worn stage clothes. Our alien friends wanted as many outfits made of weird Earth materials as possible my part-time job when not with LK was unloading shipments at The Gap - and I shipped what I gathered, as I would the evil doctor, off Earth via the wonderful transportation device I had hidden in my loft bathtub. I never asked for what purpose the scaly little creatures with the red eyes used the band's old sweaty latex, bent bruised buckles and leather, but as I had been promised that the orb would envelop us all in a rather splendiferous, fortunate glow - as it truly seemed to have, as far as this band was concerned boots. Being together two years, sharing dressing rooms and toilets as we had, and seeing one another in every which way during our rise to the toppermost-poppermost in this wacky modern music biz, Sinthia's body was still a wonder to any of us who spied it bare. But to me what was even more amazing, and a testament to what I really was all about, was that I stared at her boots more than her butt.

The band had a third set yet to deliver, and as the unbuckling, drying off and re$\rightarrow$ NATURE.COM their next round of Follow Futures on rock fetish-wear began Facebook at: go.nature.com/mtoodm (though The Cane, as we called him, kept his - LK's ever-increasing wardrobe allowance helped us all along nicely.

I left the dressing room and pulled my trench tight round my bare chest, content in the knowledge that I had once again rid the Universe of another bad character - and was collecting some smelly latex and leather for a race more enlightened than our own. .

Ralph Greco Jr is an internationally published author of short stories, plays, essays, 800 sex 'scripts', children's songs and SEO copy. Ralph is also an ASCAP licensed songwriter/performer and Internet radio DJ. Living in the wilds of suburban New Jersey, USA, Ralph attempts, yet fails, to keep his ever-expanding ego in check. 